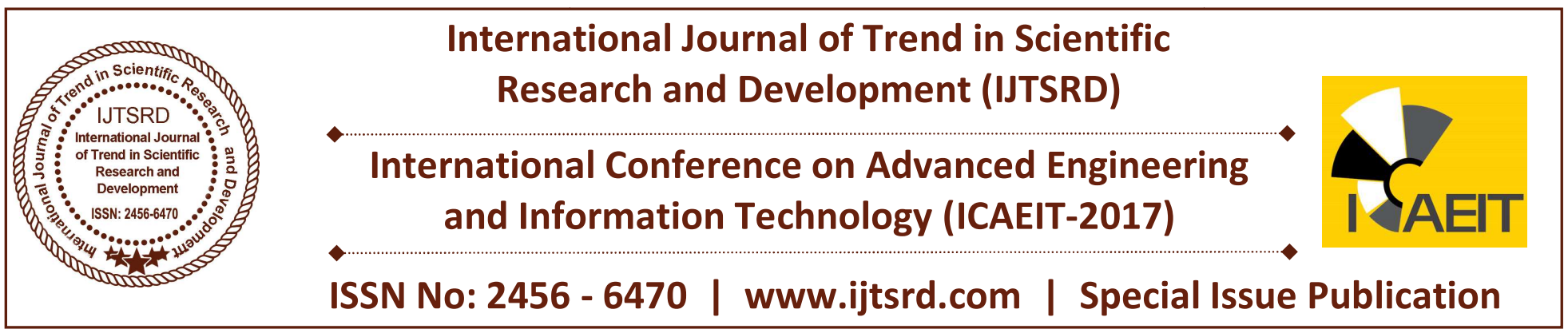

\title{
Issues on Management and Governance of Data Security In HEIs
}

\author{
Janet Gabriel $^{1}$, Sheik Mohideen Abdul Latheef ${ }^{2}$, Veluswamy Jayavardhanavelu ${ }^{1}$ \\ ${ }^{1}$ Newbridge College, Melaka, Malaysia \\ ${ }^{2}$ Faculty of Engineering and Technology, Linton University College, Malaysia
}

\begin{abstract}
In higher education, Governance of data security is the data management mechanism that has to be practiced. This is an appropriate management model for the employees in the higher education institution that will understand the role to be played to secure more highly confidential data. This paper aims at issues on management and governance of data security in Higher education institutions (HEIs). This will conclude on identifying the factors affecting governance of data security in private higher education system. It also enables to discover the issues in the management and provide appropriate solution for the governance of data security in the HEIs. A research model with factors was proposed for data security governance practice in HEIs. From the research findings, a governance model was derived and proposed for the all new HEIs.
\end{abstract}

Keywords: issues, governance; data security; higher education institutions

\section{INTRODUCTION}

The key role of governance is the way of management managing to protect the data in a highly secure manner. The institutions provide and apply specific rules and regulations but the main principle for governance is involvement, accountability and decision rights. So both security and management is different [1]. To protect the accountability and responsibility of HEIs need proper internal controls with formal informational assets in institutional structure by the security information system governance [2].

The sense of ownership revolves around the institutional staff's responsibility and accountability to provide data governance with the proper security polices in information systems security governance are crucial [3].

This paper explains the HEIs governance of data security for the information security in various fields. It coincides with the management of information security. The real world situation on data security concentrates on every element of managing secure data in whatsoever applications implemented or in use of user which involves governance of data security. The main concern is the sense of proper governance data security need to be established in ordered not to be breach of data that will be violated without the knowledge of user and administrator. This paper explains the issues on management and governance of data security in HEIs based on the research of faculty members. The main purpose is to understand and be aware of the factors that affect governance in the area of data security. The data governance values need to practice in HEIs is an important concern for data security.

The findings in this paper provide valuable information on the data governance values that have to be practice in the HEIs to upgrade the governance responsibility and accountability for the controlling and directing issues of the management [4].

This paper identifies the emerging issues in management and governance of data security and propose data security governance model for better data security in higher education industries. 


\section{Literature Review}

This paper focuses on the issues on management and governance of data security in HEIs. Data security governance enhances tight security of governance in the higher education data infringement rules and regulations.

\section{The latest trends of data security in institutions of higher education}

As the technology becomes advanced, most higher learning institutions are moving towards Mobile Learning Systems (M-LS). It has advantages and benefit but no specific standard to improve the M-LS due to multiplicities and drawback of the mobile devices [5].

Information asset's residing within the M-LS must be secured and given high priorities where it should guard the business operation, university reputation and risk and liabilities [4]. However, the responsibilities and commitment from higher education employees with regard to information security is found to be lacking [6].

Other than the M-LS, higher education need to avoid unauthorized users to access and monitor the work of professors and researchers, making sure of their research are safe in the institution and not allowing anyone to track on the information that is being accessed. More importantly, the student's confidential data and results in the computer of the institution must also be protected. Hence, the data security governance is required to facilitate all higher education users to comply with policies and best practices [7].

\section{Overview of data security in HEIs}

Teaching and Learning has been growing rapidly in the higher education. One of the important growing environments is E-learning. As people are moving faster heading towards Web 2.0, the younger generations desires for online communications and latest gadgets in the market drive towards mobile learning. Online communication and mobile computing are being the new trends for the Malaysians.

Mobile learning is a term that focuses on the learning materials which can be use through mobile devices that can be accessed at any time around the world [5]. Information accessed and dissemination has to be given importance has this is the key assets for the higher education success [4].
However, studies have highlighted that many of this educational resources are being blocked for access due to privacy reasons, complications and regulations set by the university. This is also due to the increase of security breaches as the results of the IT security policy and procedures; design for the academic purposes is in an average range [7].

Therefore, strong leadership, policies and procedures, training and awareness are needed towards the designing a proper IT security strategies for employees to handle security measures [7].

\section{Governance of data security in HEIs}

The governance in higher education institutions involves formation of policies to organize and monitor the work of management on a day today basis in their institution or administration of the institutions. The institutions resources that require access need to have conditions to access the control and a private key being generated on request, which permits the system readable to the information authorized users.

The information privacy and security are at stake when data are shared among the users and systems. Data's needed to be governed in a secure way with appropriate values and polices [8]. There are many research papers has been provided to resolve actions with what information is, when and on what conditions is and what methods used to provide to information security [9].

The various institutions have different resources, needs and beginning point. Anthony [10] stated out the point that concern on the HEIs data protect, proper usage, and protect the management of data in institutional resources.

This is being organized based on different goals and models rather than the public corporate sector, nonprofitable managements also face same type of issues such as risk, business continuity, liability, costs factor and national repercussions which are the core activities that move around the internet technology.

The use of data governance systems and polices will give more valuable advantages for the public higher education and gives more quality organizational data, provide positive effects of the data governance tools and systems on institutional strategic planning and decision making [11]. 
Information Security Scenario in Malaysia Private Higher Education

IT environment is a major part in all the higher education that deals multiple types of data, access network resources and managing databases from faculty staffs. It needs to be secured through technology as the information security is important due to the increase of computer application, internet usage and intrusions [12].

This technology has to be up to date with current technology however insufficient facilities and cost towards the technology change becomes threats to higher education. These threats causes confidentiality of data being breached and in this case experts are needed to take in charge to control and monitor over the system and threats. This process goes beyond to identify what types of security breach and kind of strategies needed to solve these issues [12].

Communication is also a barrier when dealing with data security among the faculty members where information can be misunderstood. Besides that, the organization has to support the management by having some practices, processes and policy enforcement over the data security that will help the faculty staffs in the higher education to be aware of seriousness and challenges to protect data that they are handling every day.

Hence, a proper communication channel needs to be provided for information sharing. Access rights have to be given to the faculty staffs in charge in avoiding data breach. This will support the performance of the faculty staffs towards the data security.

\section{Research Methodology}

This paper develops into the issues on management and governance of data security in HEIs. The aim is to identify new data security governance practices were to help to solve data governance problems in the higher education.

The research carried out through quantitative approach in a form of collecting survey data. The data is analyzed by using statistical method.
In the research design, qualitative method was used which consists of analytical approach focusing on the review and analysis of the literature review that will help to develop governance of data security model and empirical approach is testing the proposed model with questionnaire and verify by experts in the higher education through structure interviews. Statistical tool is used to analyze the data that been collected through questionnaire. The final solution is taken to design star data governance model. The implemented model generated a constant management and governance of data security practices in HEIs.

The research is based on the 8 hypotheses feedbacks and comments on the survey instrument. The data are collected from various faculties' staffs in higher education institutions.

\section{Findings}

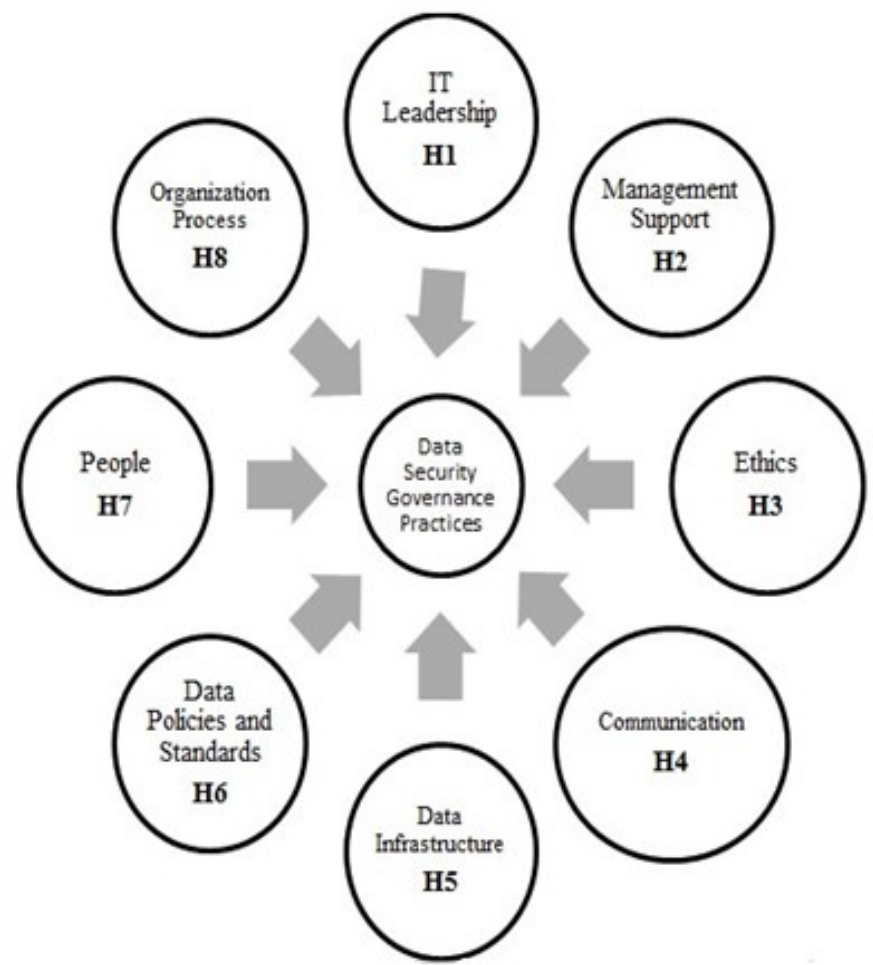

FIGURE 1: STAR GOVERNANCE MODEL OF DATA SECURITY
Independent Variables Data Security Governance Practices
Role of Variables

To achieve goals and the key performance processes for data security in the higher education through governance practices. 
International Journal of Trend in Scientific Research and Development (IJTSRD) | ISSN: 2456-647

\begin{tabular}{|c|c|}
\hline $\begin{array}{l}\text { Dependent } \\
\text { Variables }\end{array}$ & Role of Variables \\
\hline IT Leadership & $\begin{array}{l}\text { IT experts are expected to take lead control and organize the technologies in the } \\
\text { higher education institution to have better data security. }\end{array}$ \\
\hline $\begin{array}{l}\text { Management } \\
\text { Support }\end{array}$ & $\begin{array}{l}\text { To improve employee productivity in the higher education institution for better data } \\
\text { security. }\end{array}$ \\
\hline Ethics & Set of standard quality principles for data security in higher education institution. \\
\hline Communications & $\begin{array}{l}\text { To improve internal communication in the higher education institution for better } \\
\text { data security. }\end{array}$ \\
\hline $\begin{array}{c}\text { Data } \\
\text { Infrastructure }\end{array}$ & To improve data infrastructure in the higher education institution for data security. \\
\hline $\begin{array}{l}\text { Data Policies } \\
\text { and Standards }\end{array}$ & $\begin{array}{l}\text { To ensure all employees practice the policies and standard for data security in the } \\
\text { higher education institution. }\end{array}$ \\
\hline People & $\begin{array}{l}\text { To be more organized and improve the relationships among faculties' members in } \\
\text { the higher education institution for data security. }\end{array}$ \\
\hline $\begin{array}{l}\text { Organization } \\
\text { Process }\end{array}$ & $\begin{array}{l}\text { Actions being taken to maintain the data security in the higher education } \\
\text { institution. }\end{array}$ \\
\hline
\end{tabular}

TABLE 1: ROLE OF VARIABLES IN HEIs

The role of dependent and independent variables that plays in the HEIs shows the purpose of the each variable that holds a responsibility towards the HEIs.

The hypothesis has generated a constant data security value against the data governance security practices in higher education institutions.

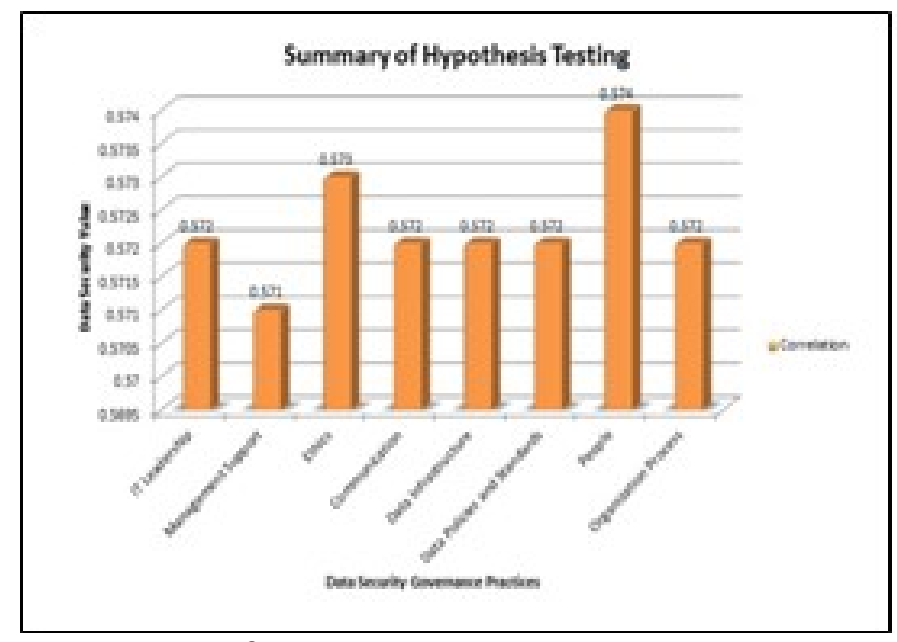

FIGURE 2: SUMMARY OF HYPOTHESIS TESTING

\section{Future Work}

There are some limitations are need to be taken into considerations through the research case study. This paper primary focus was on issues pertaining to data governance security. The primary respondents of this HEIs study are taken from the various staffs in the higher education institutions. Their view and knowledge may slightly differ among all the other institution members based on their exposure towards the governance of data security and knowledge. This paper is widely adopts the quantitative approach using questionnaire to collect data. However, the difficulties to collect information from institution staffs those who are not aware on the importance of the governance in the data security may contribute to provide a saturated linear results. Nevertheless, security measures need to be prioritized in HEI's to provide quality in organizational data management. Future research is to practically test the star data security governance factors in practically checking the feasibility that these factors actually brought to saturated values in HEIs practices in data security governance.

\section{Contribution}

This study used the eight variables of model of data security governance practice for the higher education. It has contributed eight variables which includes IT leadership, management support, ethics, communications, data infrastructure, data policies and standard, people and organization process which contribute the factors that affects the governance of data security in the higher education institutions. The eight governance's model is designed as star data governance model which shows equal weight age in data governance practices. The summarized hypothesis testing of star governance practices is to provide common average data governance security value. The identified factors will assist the IT management department of institution in identifying what is necessary to address the data security governance issues in higher education. Findings of this study have also contributed to the data security governance body of knowledge in empirically testing the identified variables in a higher education institutions HEIs context. 


\section{Conclusion}

This paper analyzes the governance of data security conceptual model for higher education in Malaysia. Based on the quantitative and qualitative survey, it was discovered that all the factors have positive relationship with the data security governance practices. As per summary of hypothesis, all the factors are influential factors that support each other. The factors are balanced that are expected to take control, organize and support each other in the HEIs to solve the issues on management and have better data security governance in higher education. Research findings shows that the governance model of data security should include IT leadership, management support, ethics, communication, data infrastructure, data policies and standards, people and organization process. All these factors have positive impact on Data governance of security based on star data governance model. Proven to be the best for the hypothesis.

\section{References}

1. Broadbent, M. (2003). Effective IT Governance by Design, Gartner Inc.

2. Dhillon, G. (2007) Principles of Information Systems Security: Text and Cases Wiley.

3. Sushma, M., \& Gurpreet, D. (2016). Information systems security governance research: A behavioural perspective.

4. Munyaradzi. M., Patrick. M., and Theo. T. (2014).The Status of Information Security
Governance within State Universities in Zimbabwe.

5. Farrah, D. S. B., Norizan, A., Noraizan, A., \& Riaza, P.M.R. (2014). Conceptualizing security measures on mobile learning for Malaysian higher education institutions. IETC. Procedia - Social and Behavioral Sciences 176 (2015), 1083 -1088.

6. Von. Solms. B. (2001). Corporate Governance and Information Security. Computers \& Security, 20, pp 215-218

7. Robert, B. K, John, V., Judith, B. C., and Judith, A. P. (2003). Information Technology Security: Governance, Strategy, and Practice in Higher Education.(5) 2003.

8. Knox, C.W., Jarl, N. \& Steve, M. (2011) Persistent Security, privacy and governance for healthcare information.

9. Rajesh, P., \& Umesh, K, S. (2012). An overview and study of security issues and challenges in cloud computing.

10. Anthony. (2014). Data Governance Overview. Protiviti Risk Business Consulting. Internal Audit.

11. Marsha. P. (2011). Applying Aspects of Data Governance from the Private Sector to Public Higher Education.

12. Md. Waliullah., Jahidul. A \& Golam, M. D. (2012). Information Technology Security, Strategies and Practices in Higher Education: A Literature Review. Journal of Computing, 4(7), July 2012. 